\title{
Analysis of groundwater quality for clean water supply in the water critical area of Kronggen Village, Brati, Grobogan District
}

\author{
${ }^{1 s t}$ Luziana Febby Nurwinandari, ${ }^{2 n d}$ T Listyani R A \\ $\{$ lis@itny.ac.id\} \\ Geological Engineering Department, Institut Teknologi Nasional Yogyakarta
}

\begin{abstract}
Groundwater quality which has been set in the Health Ministry Regulation number 492/Menkes/Per/IV/2010 has a maximum value limit to be considered feasible. This requirement becomes the standard for the feasibility of groundwater so it can be used for public consumption, including in the $\mathrm{pH}$ and TDS values. Kronggen area, in Brati Subdistrict, Grobogan Regency is a critical water area, therefore a groundwater feasibility study is needed. The objective of this research is to determine the quality of the groundwater in the area, by conducting hydrochemical measurements in the field. Result of the research shows that the groundwater in Kronggen has $\mathrm{pH}$ of $6.4-7.7$, the TDS of $311-3,539 \mathrm{ppm}$ and $\mathrm{EC}$ of $612-7,078 \mu \mathrm{S} / \mathrm{cm}$. These values indicate the nature of groundwater which is fresh to moderately saline, and most of the samples show groundwater in the medium - poor quality class.
\end{abstract}

Keywords: groundwater, quality, $\mathrm{pH}, \mathrm{TDS}, \mathrm{EC}$.

\section{Introduction}

Groundwater is water that moves / flows in the pores between the grains of soil or rock which is known as an aquifer [1]. Groundwater quality can be determined based on the content of chemical elements / compounds contained in it. The dissolution or content of these elements / compounds is strongly influenced by rock genetic and groundwater - rock interactions. Over geological time, groundwater which flows through aquifer layers will cause various processes that affect the dynamics of groundwater characteristics [2].

Kronggen Village is located in the Brati Subdistrict, Grobogan Regency (Figure 1). Grobogan Regency is one of the dry areas, has relief from the plains to karst hills. This regency, which is located between the eastern part of the North Coast and the upstream area of Bengawan Solo, has a climate type D which has $1-6$ dry and $1-6$ wet months [3]. The development of Grobogan Regency in various aspects has resulted in the increasing need for clean water, which until now still relies on groundwater. The current reality shows that in the dry season, Grobogan Regency often experiences drought [3]. One of the efforts to overcome this problem is by utilizing groundwater optimally so that it becomes a solution to fulfill the needs of clean water. 
In this case, it is important to conduct research related to the feasibility of groundwater quality related to its utilization, both as raw water and processed water that is ready for distribution. The level of damage to groundwater conditions and environment can be analyzed by measuring the parameters of acidity (pH), Total Dissolve Solid (TDS) and electrical conductance (EC). The results of the hydrochemical study in the study area are expected to provide an overview of the quality of groundwater in the Kronggen and its surroundings area.

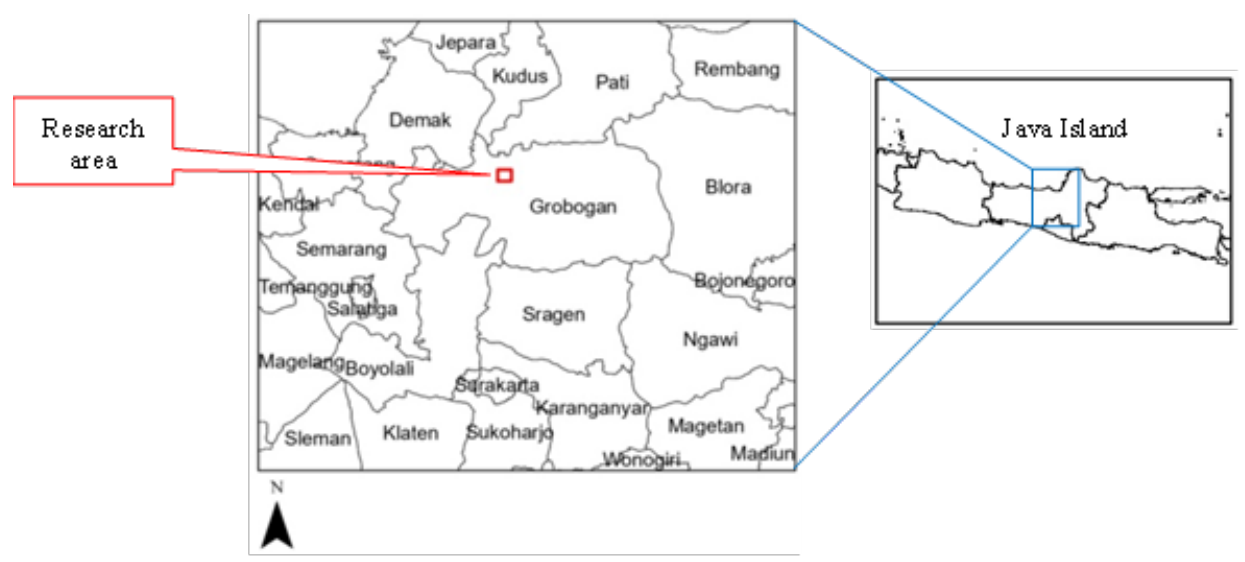

Figure 1. Observation locations of research.

\section{Literature Review}

Grobogan Regency is located in a valley between two limestone mountains, namely the Kendeng Mountains and the North Kars Mountains. Physiographically, the Grobogan area can be divided into three zones, namely the Rembang Anticlinorium (North), the Kendeng Anticlinorium (South) and the plains in the central part which is known as the Randublatung Depression [6].

The research area is included in the Regional Geological Map of the Salatiga Sheet, Java [7]. According to this geological map, the regional stratigraphy of Grobogan Regency consists of the following formations.

1. The alluvium formation (Qa), Holocene age, which consists of pebble, gravel, sand, clay, mud and plant remains, is the result of river and flood sediment from existing rivers, yellowish-gray and slightly blackish in color.

2. The Selorejo (Tps), Mundu and Tambakromo Formations, Pliocene in age, consist of claystone, marl and limestone.

3. The Ledok Formation (Tmpl), Upper Miocene age, consists of alternating calcarenite, sandstone and marl. 
4. The Kalibeng and Bulu Formation (Tmpk), Miocene in age, consists of solid marl at the top and limestone at the bottom.

5. The Wonocolo Formation (Tmw), Miocene in age, consists of marl with carbonate sandstones intercalation at the top and platy limestone at the bottom.

6. The Ngrayong Formation (Tmn), Miocene in age, consists of alternating claystone, carbonate sandstone and limestone at the bottom; and sandy claystone at the top.

The geological structures of this area are beddings of rock that have been folded. This geological structures occur mostly in rocks in the northern and southern parts of Grobogan, producing anticlines and synclines as well as strike slip and thrust faults.

\subsection{Groundwater Quality}

Groundwater quality is a qualitative condition that is measured or tested based on certain parameters and methods. Groundwater quality can be determined by the material it passes through, namely the type of soil and rock, the type of flow, and the process of physical, chemical and biological changes in water [1]. The concentration of dissolved material in groundwater can increase or decrease with the movement of water in the hydrological cycle. Thus, groundwater quality is determined by the environment that affects it during its journey $[1,8]$. The required groundwater quality depends on the intended use of the groundwater. The standards set for each requirement differ from one another [9]. The quality of groundwater that will be used for certain purposes must meet the predetermined requirements. The provisions or standards that must be met in a groundwater to be used for drinking water have been regulated in Health Ministry Regulation No. 492 / MenKes / Per / IV / 2010 [5]. The regulation stipulates a pH limit of 6.5 8.5 , while TDS $<500 \mathrm{mg} / \mathrm{L}$ is a requirement for drinking water.

\section{Methodology}

The method of research includes three stages, namely literature review, field hydrogeological survey and hydrochemical analysis. The field survey is intended as an activity to describe and collect groundwater quality data. This study uses primary data in the form of hydrochemical variables of groundwater quality, including physical (color, taste, odor) and chemical ( $\mathrm{pH}$, TDS and EC) characteristics. The research used topographic, geological and hydrogeological maps of Grobogan Regency. The hydrochemical equipment used were pH-meter, TDS-meter, and EC-meter. Data analysis was supported by ArcGIS, CorelDraw, Surfer 14 software with the Krigging method. The hydrochemical variables were analyzed by referring to the Minister of Energy and Mineral Resources Decree No. 1451.K /10/MEM/2000, concerning Technical Guidelines for Implementing Government Duties in the Field of Groundwater Management [4] as well as Health Ministry Regulation No. 492/MENKES/Per/IV/2010 concerning Requirements for Drinking Water Quality [5].

\section{Result and Analysis}

The measurement of the groundwater physical and chemical parameters. The physical parameters include color, smell, and taste; while the chemical parameters include $\mathrm{pH}$, TDS and 
EC (Table 1). The groundwater measured from dug wells, so it is shallow groundwater. The map of the observation well location is presented in Figure 2, while the example of well appearance in the field can be seen in Figure 3.

Table 1. Field data of the physical / chemical properties of groundwater.

\begin{tabular}{|c|c|c|c|c|c|c|c|}
\hline Loc. & Type & Color & Taste & Odor & $\mathrm{pH}$ & TDS & EC \\
\hline W1 & Well & Colorless & Moderately Saline & Odorless & 6.6 & 3,091 & 6,181 \\
\hline W2 & Well & Colorless & Moderately Saline & Odorless & 6.6 & 3,539 & 7,078 \\
\hline W3 & Well & Colorless & Moderately Brackish & Odorless & 6.5 & 1,792 & 1,694 \\
\hline W4 & Well & Colorless & Fresh & Odorless & 7.7 & 311 & 612 \\
\hline W5 & Well & Colorless & Fresh & Odorless & 7.5 & 311 & 624 \\
\hline W6 & Well & Colorless & Moderately Brackish & Odorless & 6.8 & 3,025 & 6,050 \\
\hline W7 & Well & Colorless & Moderately Brackish & Odorless & 6.9 & 1,861 & 1,722 \\
\hline W8 & Well & Colorless & Moderately Brackish & Odorless & 6.6 & 1,811 & 3,434 \\
\hline W9 & Well & Colorless & Moderately Brackish & Odorless & 6.4 & 1,267 & 2,534 \\
\hline W10 & Well & Colorless & Moderately Brackish & Odorless & 6.4 & 1,576 & 1,954 \\
\hline W11 & Well & Colorless & Moderately Brackish & Odorless & 6.6 & 1,677 & 2,178 \\
\hline
\end{tabular}

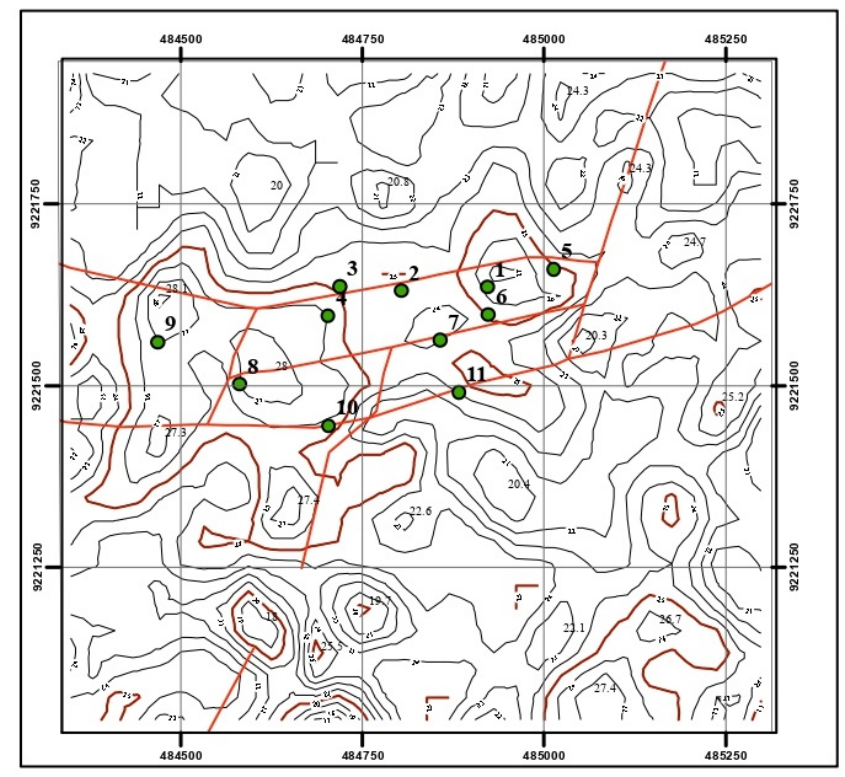

Figure 2. The location map of dug wells in research area (scale 1: 10,000). 

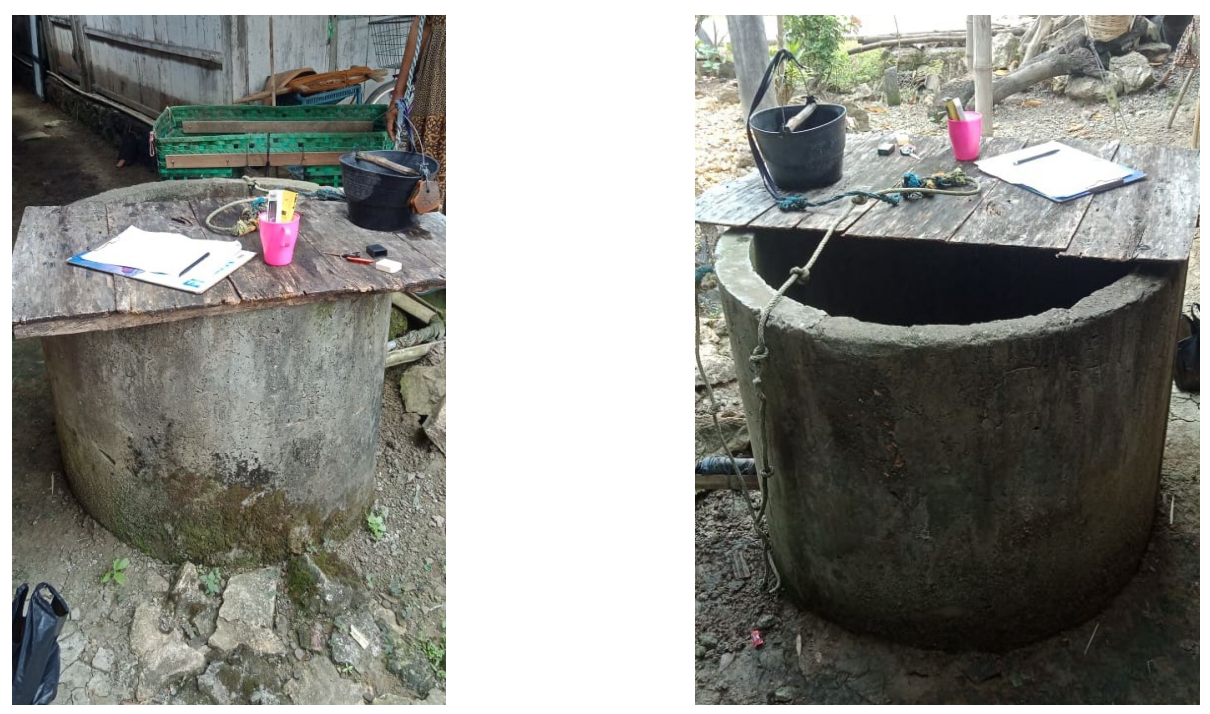

Figure 3. One of the features of a dug well (W8).

The $\mathrm{pH}$ measurement of groundwater in the study area showed a value ranging from 6.4 to 7.7 (Table 1). There were 8 wells with acidic $\mathrm{pH}$ values $(6.4-6.9)$ and 2 wells with slightly alkaline $\mathrm{pH}$ values $(7.5-7.7)$. This $\mathrm{pH}$ value indicates that groundwater is relatively neutral to slightly acidic. This acidity is possible due to the influence of rainfall or organic substances in the soil. Groundwater in W9 and W10 does not comply with drinking water quality standards issued by the Minister of Health [5]. As for referring to the regulation of the Minister of Energy and Mineral Resources [4] where the maximum $\mathrm{pH}$ value is 7.5 , then $\mathrm{W} 4$ can be categorized as having poor groundwater quality, while other wells are of medium quality. The $\mathrm{pH}$ map of groundwater is presented in Figure 4.
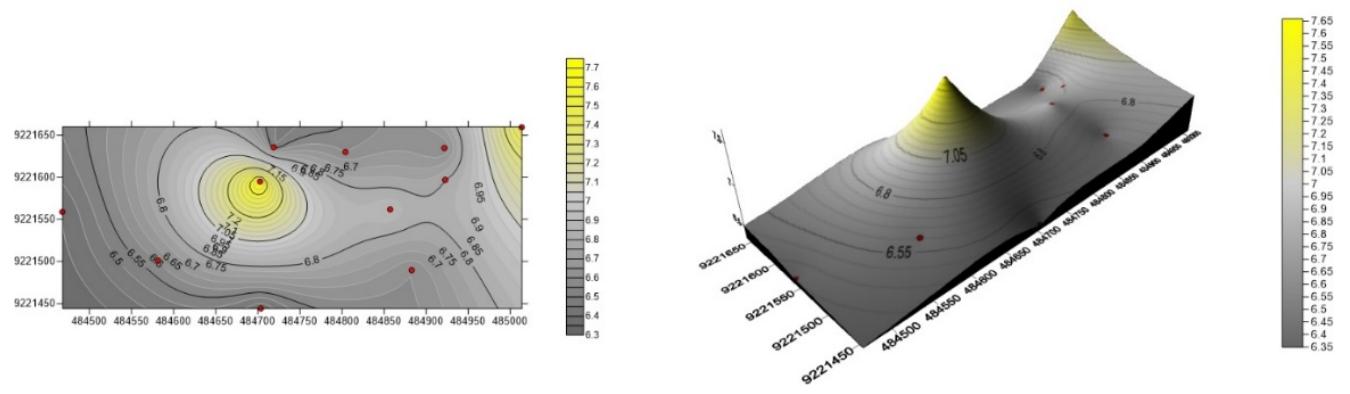

Figure 4. The map of groundwater $\mathrm{pH}$ distribution at the research area.

Map of TDS value of groundwater in research area is perfomed in Figure 5 below. The TDS value of groundwater usually indicate the groundwater condition levels [4]. Based on the Minister of Energy and Mineral Resources Decree No. 1451.K /10/MEM/2000, the maximum TDS value of groundwater as a recommended requirement for drinking water is $500 \mathrm{mg} / \mathrm{L}$, and the maximum value allowed is $1,500 \mathrm{ppm}$. The quality of the groundwater in research area generally has a value $>1,500 \mathrm{ppm}$. According to the regulation, groundwater was generally of poor quality, except for W4 and W5 which were of good quality and W9 which were of medium 
one. Now, many water sources have critical value. TDS values that reach 1,500 $\mathrm{mg} / \mathrm{L}$ are highly recommended not for human consumption. With a high TDS number, it is necessary to have further treatment.
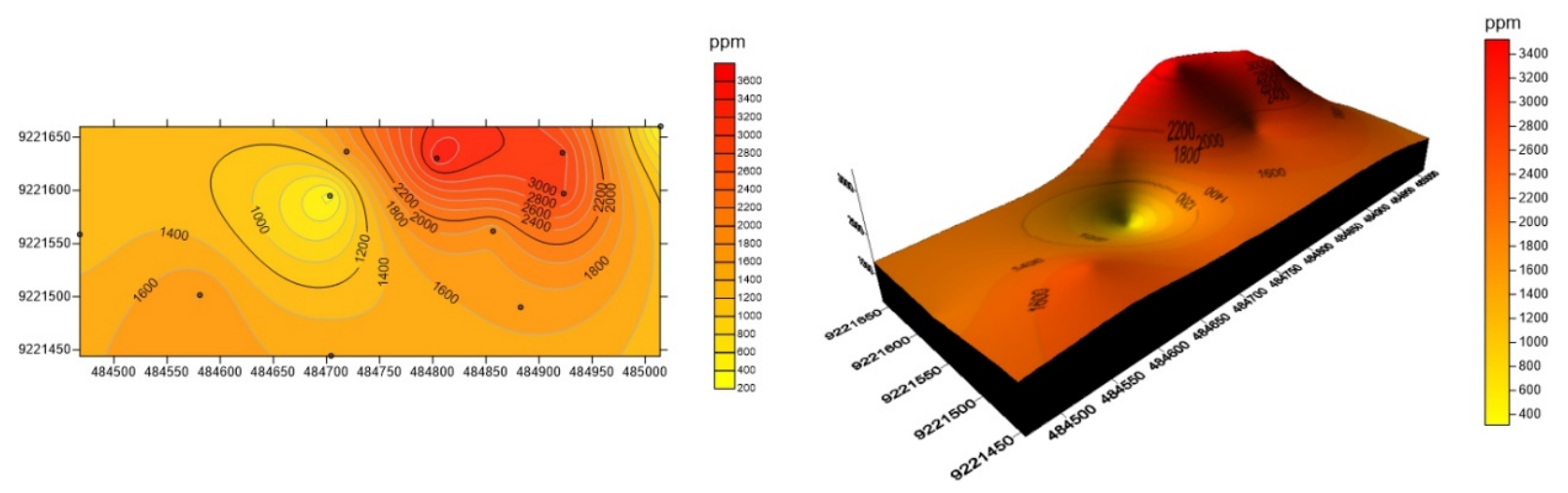

Figure 5. TDS distribution map of groundwater in the research area.

The distribution of groundwater EC map in study area can be seen in Figure 6. Groundwater in the reasearch area can be classified as moderately saline groundwater according to Hem (1970 in [10]), or brackish water according to Carroll (1962 in [1]), except for groundwater in W4 and W5 which is still fresh. The EC values of groundwater in the study area ranged from $612-7,075 \mu \mathrm{S} / \mathrm{cm}$, indicating fresh to brackish groundwater. This poor quality of groundwater requires further treatment if it will be used as drinking water. High EC values can occur due to contamination or large dissolved salts of rock minerals.
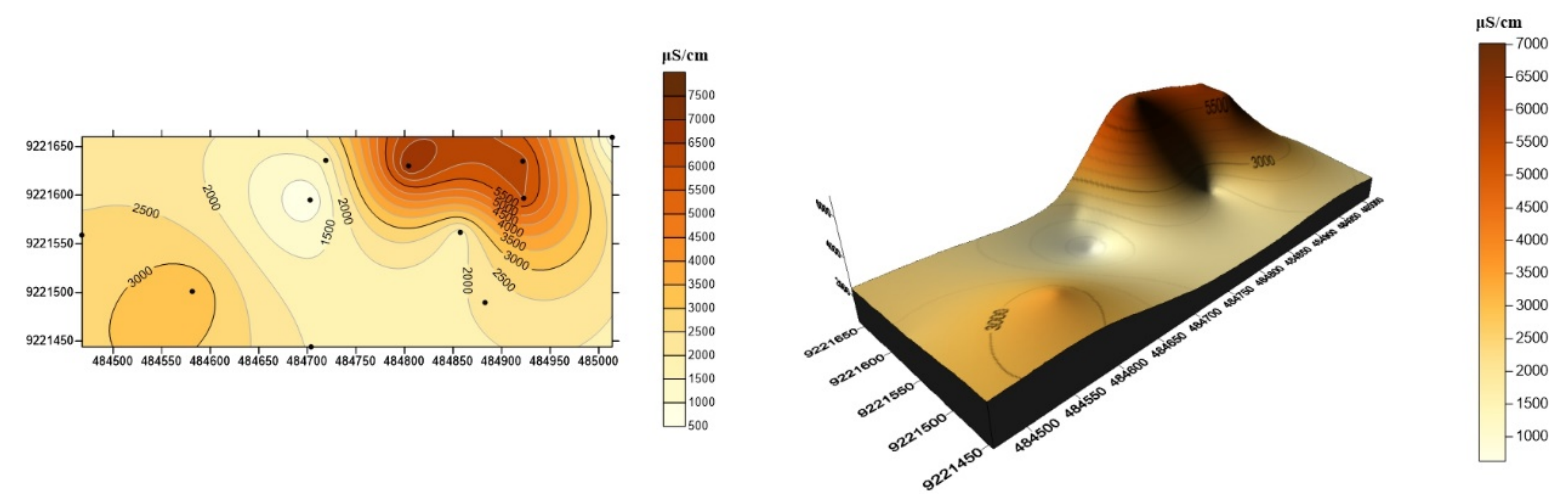

Figure 6. The EC of groundwater distribution map of the research area.

The shallow groundwater aquifers in Grobogan Regency are generally composed of limestone, marl, sandstone limestone, claystone and alluvial deposits which form the Randublatung depression [11].The reaction of groundwater to the minerals in these rocks support the formation of brackish water. The aquifer's lithology supports high conductivity (EC) in water, so that the 
water will be brackish to salty taste [12]. The relatively alkaline groundwater in W4 may be influenced by the solubility of minerals in limestone, marl or sandy limestone. Thus, groundwater in the research area needs special treatment for groundwater so that it is suitable for consumption.

In general, the quality of groundwater in Kronggen area are of poor quality refers to government regulations $[1,2]$. The analysis is mainly based on hydrochemical parameters of $\mathrm{pH}$ and TDS values (Table 2). From all dug wells studied, only one sample has good quality groundwater, two samples are of medium quality, the rest is of poor quality.

Table 2. Suitability of groundwater quality to government regulations [1,2] based on chemical parameters.

\begin{tabular}{|c|c|c|c|c|c|}
\hline \multirow[b]{2}{*}{ Well } & \multicolumn{2}{|c|}{$\mathrm{pH}$} & \multicolumn{2}{|c|}{ TDS } & \multirow[b]{2}{*}{$\begin{array}{c}\text { Resume } \\
\text { of } \\
\text { Quality }\end{array}$} \\
\hline & $\begin{array}{c}6.5-8.5 \\
{[1]}\end{array}$ & $\begin{array}{c}\leq 7.5 \\
{[2]}\end{array}$ & $\begin{array}{c}\text { Max } \\
\text { Suggestion } \\
(500 \mathrm{ppm}) \\
{[1]} \\
\end{array}$ & $\begin{array}{c}\text { Max } \\
\text { Permition } \\
(1,500 \mathrm{ppm}) \\
{[1]} \\
\end{array}$ & \\
\hline W1 & $\sqrt{ }$ & $\sqrt{ }$ & $\mathrm{X}$ & $\mathrm{X}$ & Poor \\
\hline W2 & $\sqrt{ }$ & $\sqrt{ }$ & $\mathrm{X}$ & $X$ & Poor \\
\hline W3 & $\sqrt{ }$ & $\sqrt{ }$ & $X$ & $X$ & Poor \\
\hline W4 & $\sqrt{ }$ & X & $\sqrt{ }$ & $\sqrt{ }$ & Moderate \\
\hline W5 & $\sqrt{ }$ & $\sqrt{ }$ & $\sqrt{ }$ & $\sqrt{ }$ & Good \\
\hline W6 & $\sqrt{ }$ & $\sqrt{ }$ & X & X & Poor \\
\hline W7 & $\sqrt{ }$ & $\sqrt{ }$ & X & $X$ & Poor \\
\hline W8 & $\sqrt{ }$ & $\sqrt{ }$ & $\mathrm{X}$ & $X$ & Poor \\
\hline W9 & $\mathrm{X}$ & $\sqrt{ }$ & X & $\sqrt{ }$ & Moderate \\
\hline W10 & $\mathrm{X}$ & $\sqrt{ }$ & $\mathrm{X}$ & $X$ & Poor \\
\hline W11 & $\sqrt{ }$ & $\sqrt{ }$ & $\mathrm{X}$ & $X$ & Poor \\
\hline
\end{tabular}

\section{Conclusion}

Based on the groundwater quality analysis, the Kronggen area at Brati Subdistrict, Grobogan Regency, Central Java show the groundwater that is not in accordance with water quality standards. This analysis is mainly based on chemical parameters such as $\mathrm{pH}$, TDS, and EC. The $\mathrm{pH}$ value of groundwater is slightly acidic to neutral, or slightly alkaline. TDS and EC values of groundwater generally indicate the largely brackish, with the exception of two wells (W4 and W5) which have fresh groundwater. In accordance with the parameters required in Health Ministry Regulation No. 492 year 2010 and Minister of Energy and Mineral Resources Decree No. $1451 . \mathrm{K} / 10 / \mathrm{MEM} / 2000$, groundwater in the research area is generally classified as medium - poor quality groundwater, with TDS values ranging from 311-3,539 ppm and EC from 612 $7,078 \mu \mathrm{S} / \mathrm{cm}$. 


\section{Acknowledgment}

The authors would like to thank to ITNY and especially the Geological Engineering Study Program for facilitating the publication of this paper.

\section{References}

[1] Todd D K 1980 Groundwater Hydrology 2nd Ed. (New York: John Willey \& Sons Inc.)

[2] Kodoatie R J 1996 Pengantar Hidrogeologi (Yogyakarta: Penerbit Andi).

[3] Rahayu E S and Irianto H 2013 Kajian Keragaan Pasar dan Daya Saing Komoditas Tembakau sebagai Dampak Perubahan Iklim di Kabupaten Grobogan, Jurnal SEPA, 9(2).

[4] Ministry of Energy and Mineral Resources of Republic Indonesia 2000 Minister of Energy and Mineral Resources Decree Number 1451.K/10/MEM/2000 concerning Technical Guidelines for the Implementation of Government Duties in the Discipline of Groundwater Management.

[5] Health Ministry of Republic Indonesia 2010 Health Ministry Regulation No. 492/MenKes/Per/IV/2010 concerning Quality Requirements of Drinking Water.

[6] Van Bemmelen R W 1949 The Geology of Indonesia Vol. 1A (The Hague, Netherland: Martinus Nijhoff).

[7] Sukardi and Budhitrisna T 1992 Geological Map of Salatiga Sheet, Java, scale 1:100.000. (Bandung: Geological Research and Development Center).

[8] Listyani R A T and Peni S N 2020 Potential of Water Pollution in Girimulyo, West Progo, 1st INCRID, Diponegoro University, Semarang, https://iopscience.iop.org/article/10.1088/17551315/448/1/012038/pdf.

[9] Wijaya T, Saputra A A C, Putranto T T, and Kusuma I A 2017 Studi Kerentanan Airtanah terhadap Pencemaran dan Pemompaan dengan Metode Groundwater Occurrence, Overlaying Lithology, dan Depth of Groundwater (GOD) di Kecamatan Grobogan dan Kecamatan Purwodadi, Kabupaten Grobogan, Provinsi Jawa Tengah, Faculty of Engineering Diponegoro University.

[10] Bouwer H 1978 Land Treatment of Wastewater in Today's Society, Civil Engineering 48(1) 78-81.

[11] Yuwana N A J, Pandjaitan N H and Waspodo R S B 2017 Prediksi cadangan air tanah berdasarkan hasil pendugaan geolistrik di Kabupaten Grobogan, Jawa Tengah, Jurnal Sumber Daya Air 13(1), 2336.

[12] Mahida U N 1986 Pencemaran dan Pemanfaatan Limbah Industri (Jakarta: Rajawali). 